\title{
Piotr Legutko, Dobrosław Rodziewicz. 2011. Mity czwartej władzy. Poznań: Wydawnictwo Zysk i S-ka, ss. 260
}

D rugie wydanie książki krakowskich dziennikarzy ukazało się osiem lat po pierwszym. Jak piszą autorzy: „przez te osiem lat zmieniło się w polskim świecie medialnym tak wiele, że prawie wszystko pozostało po staremu". Choć nie jest to zbyt zachęcająca konstatacja, nie należy wyciągać pochopnych wniosków, że wydana przez poznańskie Wydawnictwo Zysk i S-ka książka nie ma nic nowego do zaoferowania czytelnikom, związanym ze światem mediów i komunikacji. Nowe wydanie zaktualizowano, uporządkowano i poszerzono o rozdział poświęcony nowym mediom, które przez owe osiem lat dynamicznie rozwinęły się na polskim rynku medialnym.

Co równie warte podkreślenia, obaj autorzy książki są dziennikarzami z wieloletnim doświadczeniem w różnych typach mediów, redakcjach i na licznych stanowiskach. Z jednej strony, ich medialna praktyka dała możliwość jak najbliższej i dokładnej wiwisekcji mediów w Polsce. Z drugiej, przynajmniej pozornie, utrudniła nabranie dystansu do analizowanego materiału. Rzadko można spotkać dokładny i naukowo spójny dziennikarski opis mediów. Zwykle są one obciążone całym szeregiem kategoryzacyjnych i typologicznych uproszczeń właściwych warsztatowi dziennikarskiemu, które wpływają na jakość finalnego materiału. W książce Piotra Legutki i Dobrosława Rodziewicza mamy do czynienia z jednym z dokładniejszych przedstawień świata polskich mediów od środka. Warto zwrócić uwagę na zachowaną - poza kilkoma fragmentami - poprawność metodologiczną, terminologiczną i typologiczną zawartą w rozważaniach autorów. Mimo że nie ustrzegli się błędów symplifikacji, wydaje się, że Mity... mogą zostać w pełni wykorzystywane jako wartościowe źródło wiedzy o realiach funkcjonowania polskich mediów.

Dotychczas do określenia tematyki Mitów... stosowałem kategorię możliwie jak najszerszą - mediów. O czym zatem jest ta książka? Media to zdecydowanie uproszczenie, recenzowana publikacja podejmuje bowiem głównie trzy kwestie. Pierwszą jest demitologizacja pewnych „mitów”, a raczej przekonań, które o dziennikarzach i mediach mają ich odbiorcy, ale również sami dziennikarze i osoby z mediami związane. Drugą jest nakreślenie zależności między elementami triady relacji systemowych, w których media funkcjonują. Autorzy, przytaczając przykła- 
dy, ukazują, jak w Polsce media balansują między systemem polityki i systemem gospodarki. Trzecią jest opis rozwoju, deregulacji i tendencji występujących na polskim rynku medialnym, począwszy od 1989 roku. Każdy z trzech pokazanych tematów obfituje w szereg przykładów i rzetelnych opisów, które dają stosunkowo dokładny obraz funkcjonowania mediów masowych w Polsce. Na szczególną uwagę zasługują próby przedstawienia zmian, jakie zachodziły i zachodzą na rynku medialnym. Dzięki temu Mity... stanowią wartościowe źródło wiedzy naukowej, niezbędnej do orientacji w realiach polskiego systemu medialnego.

Autorzy już na początku rozważań dokonali wartościowego, a zarazem potrzebnego zabiegu dookreślenia podstawowej kategorii, którą badają - czwartej władzy. W rodzimej literaturze przedmiotu kategoria ta jest nader często wykorzystywana bezrefleksyjnie. Jest to jeden z błędów w wielu pracach naukowych, a wynika bezpośrednio z mylnego tłumaczenia angielskiego pierwowzoru the fourth estate. Poprawnie należałoby tłumaczyć tę kategorię jako czwarty stan. Legutko i Rodziewicz opisują genezę i znaczenie kategorii czwartej władzy, jednak - jak zauważają - w Polsce dominuje postrzeganie dziennikarstwa jako „kontrolera jakości" życia publicznego, ze szczególnym akcentem na polityków. Tym właśnie tłumaczą konsekwentne posługiwanie się terminem zastosowanym przez nich $w$ tytule książki.

W kolejnych odsłonach publikacji krakowscy dziennikarze demaskują „mity”, którymi obrosło polskie dziennikarstwo i media. Pierwszym z nich jest mit ładu spontanicznego, który wyjaśnia, jak rodził się polski system medialny. Drugi to mit dziennikarskiej kompetencji, w którym autorzy pokazują, dlaczego dziennikarze nie widzą ani więcej, ani lepiej. Trzeci to mit niezależności, gdzie przedstawiono szereg możliwości nacisku na media i dziennikarzy. Czwarty to mit obiektywizmu. Następne to mity: manipulacji; pożytku publicznego; rzeczywistości; innych mediów.

Medioznawcy, począwszy od przełomowej pracy Waltera Lippmanna Public Opinion, prowadzą badania nad podejmowaniem decyzji w pracach redakcyjnych i dziennikarskich. Często takie analizy krążą wokół tematyki kompetencji, wiedzy i profesjonalizmu dziennikarzy. Jednak stosunkowo rzadko spotyka się analogiczne spostrzeżenia, wychodzące z samego środowiska dziennikarskiego. Tym bardziej należy zwrócić uwagę na to, co o tym zagadnieniu piszą Legutko i Rodziewicz, zwłaszcza że konstatują oni, iż:

każda, nieco tylko baczniejsza, a systematyczna obserwacja tego, co dziennikarze robią naprawdę, musiałaby bowiem ujawnić, że wcale nie tak rzadko plotą niestworzone rzeczy, zadają rozmówcom niemądre pytania i zdradzają spore luki w znajomości tematów, które poruszają. Miliony złotych mylą z miliardami, a skutki z przyczynami, mieszają nazwiska i funkcje, przekręcają nazwy, wyolbrzymiają sprawy błahe, zapominając o najważniejszych, snują bezpodstawne 
spekulacje, powołują się na cudze relacje i opinie bez sprawdzenia ich wiarygodności w innych źródłach itd., itp. (s. 60).

Z powyższego wynika, że praca polskich dziennikarzy i pracowników mediów wpisuje się w koncepcję fast thinking Pierre'a Bourdieu. W tak rozumianym dziennikarstwie, szczególnie telewizyjnym, nie ma znaczenia przygotowanie warsztatowe dziennikarzy, a zdolność do stosunkowo szybkiego przekazywania informacji, opinii. Przy czym nieważne jest, czy dziennikarze wykazują się wiedzą merytoryczną, ale jak skutecznie i dynamicznie będą w stanie zakomunikować pewne, ogólnie rozumiane treści.

W części poświęconej mitowi medialnej niezależności autorzy przedstawiają różnice między formalnymi zapisami prawnymi a rzeczywistością pracy w mediach, która podlega szeregowi nacisków, zarówno ze świata polityki, jak i rynku. Legutko i Rodziewicz wymieniają kolejne kręgi, w które wchodzi dziennikarz, a od których w pewnym sensie się uzależnia. Kręgi, ale i inne pokazane mechanizmy, są swoistą analogią do filtrów medialnych w koncepcji propagandy Noama Chomsky'ego i Edwarda Hermana.

W licznych książkach i artykułach z zakresu komunikacji społecznej autorzy podejmują rozważania dotyczące obiektywizmu dziennikarskiego i budowania obiektywnej rzeczywistości medialnej. Także w Mitach... czytelnicy mogą trafić na podobne analizy. Zdaniem krakowskich dziennikarzy "słowa »obiektywizm« i »obiektywny« w odniesieniu do świata mediów i dziennikarstwa mają tak nikłą wartość poznawczą, że najrozsądniej byłoby z nich w opisywaniu tego świata zrezygnować" (s. 131). Obalając ten mit, wskazują jednocześnie na dwa rozumienia, ich zdaniem najbardziej odpowiadające kategorii „obiektywizmu”. Są to kolejno: dążenie do poznania i przekazywania prawdy, niezależnie od tego, jaka jest; dążenie do faktycznej afirmacji wartości wspólnych, ładu społecznego, dzięki czemu staranie o prawdę porządkuje świat. Jednak gdybyśmy próbowali dowiedzieć się, czym owa prawda jest, to książka nie daje nam satysfakcjonującej odpowiedzi. Wydaje się bowiem, że „obiektywizm" - słusznie przez autorów "obalony” - jest tak samo poznawczo i komunikologicznie nieużyteczny co "prawda".

Podobny zarzut można mieć do innej „wątpliwej” kategorii medioznawczej, jaką jest "manipulacja”. Autorzy, wprowadzając podział na manipulację mityczną i faktyczną, nie próbują teoretycznie opisać "manipulacji”, a jedynie wskazują na szereg technik, które za manipulacje mogą być uważane. Technik przydatnych głównie do obserwacji medialnej praktyki, które przy próbie wyczerpującego opisu nie mogą być uważane za zasadne do zastosowania.

Ostatnim punktem o dużym znaczeniu dla całości książki jest rozdział poświęcony nowym mediom. Choć w zasadzie, co można wnioskować z opisu w Mitach..., „nowym mediom”. Legutko i Rodziewicz zdecydowanie stoją w opozycji do zachwytów nad nowymi technikami komunikacji, stwierdzając ich stosunko- 
wo nieduży wpływ na pracę dziennikarzy. Ich zdaniem „nowe media”, choć niewątpliwie zmieniły postrzeganie zawodu i formę pracy mediów, nie oddziałują silnie na treść nowomedialnych przekazów. Tym samym krakowscy dziennikarze wpisują się w coraz silniejszy nurt polskiego medioznawstwa, w którym odrzucany jest podział na media stare i nowe.

Podsumowując, trzeba raz jeszcze podkreślić wartość Mitów... jako analizy medioznawczej. Autorzy w wielu miejscach książki (zaledwie kilka z nich zostało pokazanych $w$ recenzji) znacząco i dokładnie opisują polskie media - system medialny oraz praktykę dziennikarską. Z dobrym, a służącym pracy dystansem podchodzą do autoopisu mediów oraz wyciągają ciekawe wnioski. Pomimo faktu, że książka nie jest pracą naukową i znajdują się w niej właściwe takim formom uogólnienia oraz błędy, wynikające z braków metodologicznych, całość należy ocenić bardzo dobrze. W wielu aspektach książka jest dokładniejsza oraz bardziej interesująca niż wiele prac naukowych, w których podjęto podobne próby charakterystyki polskich mediów. Tym bardziej należy mieć nadzieję, że Mity... będą wykorzystywane w praktyce naukowej i dydaktycznej jako dobre źródło informacji o dziennikarstwie oraz mediach w Polsce.

Łukasz Wojtkowski

(Uniwersytet Mikołaja Kopernika w Toruniu) 